EOMmUn Communication et organisation

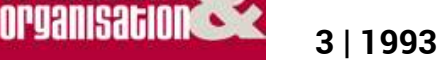

Le changement organisationnel

\title{
La vie des organisations
}

Lee Thayer

\section{OpenEdition}

Journals

Édition électronique

URL : http://journals.openedition.org/communicationorganisation/1617

DOI : 10.4000/communicationorganisation. 1617

ISSN : 1775-3546

\section{Éditeur}

Presses universitaires de Bordeaux

\section{Édition imprimée}

Date de publication : 1 mai 1993

ISSN : 1168-5549

\section{Référence électronique}

Lee Thayer, "La vie des organisations », Communication et organisation [En ligne], 3| 1993, mis en ligne le 26 mars 2012, consulté le 01 mai 2019. URL : http://journals.openedition.org/ communicationorganisation/1617 ; DOI : 10.4000/communicationorganisation.1617

Ce document a été généré automatiquement le 1 mai 2019

(C) Presses universitaires de Bordeaux 


\title{
La vie des organisations
}

\author{
Lee Thayer
}

\section{RÉSUMÉS}

Cet essai propose une réflexion sur les finalités de la communication et de l'organisation. Rappelant les liens étroits qui rendent ces dernières indissociables, l'auteur soutient que l'organisation doit être considérée comme un moyen au service de fins humanistes et non comme une fin en soi. Il explore ensuite les changements qu'implique cette perspective sur nos façons de concevoir certains processus organisationnels, la communication et l'activité de théorisation elle-même. Pour obtenir des systèmes de communication/ organisation qui contribuent à l'épanouissement des êtres humains, l'auteur propose une conception triadique de la communication qui, en plus de faire appel à des partenaires dotés de «compétences de communication », fait intervenir une vision de l'idéal qu'ils choisissent de poursuivre.

This essay considers the purposes of communication and organization. The author begins by showing how communication and organization are interwoven with each other to form a nondecomposable reality and goes on to assert that organizations must be considered as means to human ends, and not as ends in themselves. This perspective, the author argues, leads to important changes in our conception of organizational processes, of communication and even of theory. Some of the Implications of these changes are explored. To show how organization / communication Systems may en-hance the human being, the author proposes a triadic conception of communication which implies partners provided with «communicative competencies ", but also a vision of the idéal they are trying to reach. 


\section{AUTEUR}

\section{LEE THAYER}

L'auteur était jusqu'à tout récemment professeur au département de communication de l'Université de Wisconsin-Parkside. Il est actuellement professeur invité à l'Université de Brisbane en Australie. Il fait partie des pionners dans le domaine des communications organisationnelles. Ses écrits théoriques sont uniques et internationalement connus. 